\title{
Clinical and Genetic Findings of Five Patients with WTI-Related Disorders
}

clinical case report

Juliana GabRIEL R. DE ANDRADE

Mara Sanches Guaragna

FERNANDA Caroline SOARDI

GIL GUERRA-JÚNIOR

Maricilda Palandi de Mello

ANdRÉa Trevas Maciel-GuerRa

Grupo Interdisciplinar de Estudos da Determinação e

Diferenciação do Sexo (GIEDDS),

Faculdade de Ciências Médicas,

Universidade de Campinas

(Unicamp) (JGRA, GGJ, ATMG);

Centro de Biologia Molecular e Engenharia Genética (CBMEG),

Unicamp (MSG, FCS, MPM);

Campinas, SP, Brasil.

Received in 25/8/2008

Accepted in 14/10/2008
Aim: To present phenotypic variability of WT1-related disorders. Methods: Description of clinical and genetic features of five $46, X Y$ patients with WT1 anomalies. Results: Patient 1: newborn with genital ambiguity; he developed Wilms tumor (WT) and chronic renal disease and died at the age of 10 months; the heterozygous $1186 \mathrm{G}>\mathrm{A}$ mutation compatible with Denys-Drash syndrome was detected in this child. Patients 2 and 3: adolescents with chronic renal disease, primary amenorrhea and hypergonadotrophic hypogonadism; patient 2 had a gonadoblastoma. The heterozygous IVS9+4, C>T mutation, compatible with Frasier syndrome was detected. Patient 4: 9-year-old boy with aniridia, genital ambiguity, dysmorphisms and mental deficiency; a heterozygous 11p deletion, compatible with WAGR syndrome was detected. Patient 5: 2 months old, same diagnosis of patient 4; he developed WT at the age of 8 months. Conclusions: Constitutional abnormalities of WT1 cause gonadal and renal anomalies and predisposition to neoplasia and must be investigated in patients with ambiguous genitalia, chronic renal disease and(or) Wilms tumors; primary amenorrhea with chronic renal disease; and aniridia, genital ambiguity and dysmorphisms. (Arq Bras Endocrinol Metab 2008; 52/8:1236-1243)

Keywords: Sex differentiation; WT1 gene; Denys-Drash syndrome; Frasier syndrome; WAGR syndrome

\section{RESUMO}

\section{Achados Clínicos e Genéticos de Cinco Pacientes com Anomalias Relacionadas ao Gene WT1.}

Objetivo: Descrever a variabilidade fenotípica das anomalias relacionadas ao WT1. Métodos: Descrição das características clínicas e genéticas de cinco pacientes 46,XY com anomalias no WT1. Resultados: Paciente 1: Recém-nascido com ambigüidade genital desenvolveu tumor de Wilms (TW) e insuficiência renal crônica (IRC), com óbito aos 10 meses. Detectada a mutação 1186G>A em heterozigose, compatível com síndrome de Denys-Drash. Pacientes 2 e 3: Adolescentes com IRC, amenorréia primária e hipogonadismo hipergonadotrófico; a paciente 2 apresentava gonadoblastoma. Ambas apresentavam mutação IVS9+4, C>T em heterozigose, característica da síndrome de Frasier. Paciente 4: Idade 9 anos, aniridia, ambigüidade genital, dismorfismos e deficiência mental; deleção 11p, compatível com síndrome WAGR foi encontrada em heterozigose. Paciente 5: Dois meses, mesmo diagnóstico do paciente 4, desenvolveu TW aos 8 meses. Conclusões: Alterações constitucionais do WT1 determinam anomalias gonadais, renais e predisposição a neoplasias; devem ser pesquisadas em casos de ambigüidade genital associada a IRC e(ou) TW; de amenorréia primária com IRC; e aniridia, ambigüidade genital e dismorfismos. (Arq Bras Endocrinol Metab 2008; 52/8:1236-1243)

Descritores: Diferenciação sexual; Gene WT1; Síndrome de Denys-Drash; Síndrome de Frasier; Síndrome WAGR 


\section{INTRODUCTION}

ex determination is a complex and yet not fully elucidated process which depends on a complex network of interrelated genes. Gonadal development starts by the end of the $5^{\text {th }}$ week of gestation with the migration of primordial germ cells from the yolk sac to the gonadal anlage. Formation of the primordial gonads, which have no apparent sexual differences up to 8 weeks, depend on the expression of many genes, including SF-I (steroidogenic factor I) (1), DAXI (dosagesensitive sex reversal, adrenal hypoplasia critical region, on chromosome X, gene 1) (2) and WTI (Wilms tumour 1) (3).

WTI (OMIM 607102) is located at $11 \mathrm{pl} 3$ and encodes a zinc finger motif-containing transcription factor involved in regulation of growth and differentiation (4). Beyond its role in the genesis of Wilms tumour (5-6), it regulates early gonad and kidney development (7).

Alternative splicing generates four major $W T 1$ isoforms: an alternative splice site in intron 9 allows the addition of three amino acids (KTS) between zinc fingers 3 and 4 and the fifth exon, encoding 17 aminoacids, may or may not be present. These isoforms are highly conserved among different species and play a crucial role in normal gene function. Gene action depends on the predominant isoform: WTl (-KTS) variants act as transcriptional regulators, while WTI $(+\mathrm{KTS})$ participates on the regulation of certain genes at the post-transcriptional level (8-10).

WTI (-KTS) isoforms act in association with the product of SF-I to promote expression of anti-müllerian hormone $(\mathrm{AMH})$, responsible for regression of the müllerian ducts in male embryos. The product of DAXI can repress the synergistic action of WTI and SF-1, resulting in down-regulation of AMH (11). In vitro experiments suggested that WTI (-KTS) variants are also responsible for transcriptional activation of $S R Y$, which activates the male differentiation pathway (10).

Mutations in WTI are found in a variety of syndromes, including Denys-Drash (DDS, OMIM 194080), Frasier (FS, OMIM 136680) and WAGR (OMIM 194072 ) syndromes. Both DDS and FS are characterized by gonadal and renal anomalies and predisposition to neoplasia associated with "de novo" constitutional WTI point mutations with a negative dominant effect (12).

In DDS, mutations often occur in the zinc finger region abolishing DNA binding capacity and leading to sex ambiguity as a result of dysgenetic testis, diffuse mesangial sclerosis with chronic renal disease and high incidence of Wilms tumour (WT) (13-14). The clinical picture of FS includes dysgenetic gonads with male-tofemale sex reversal in 46,XY subjects and pubertal delay in both sexes, nephrotic syndrome and focal segmental glomerulosclerosis leading to chronic renal disease, and high incidence of gonadoblastoma but not of WT. Mutations in FS affect the splice site in intron 9, with $W T l(+\mathrm{KTS})$ isoforms (15-16) losses.

WAGR ( $\underline{\text { WT}}$, aniridia, genitourinary malformations, mental retardation) is a contiguous gene syndrome arising from deletions of chromosome $11 \mathrm{pl} 3$ which encompass at least both the PAX6 and WTI genes (17-19).

We report five patients followed in a reference service for disorders of sex development which illustrate the broad spectrum of presentation of WTl-associated disorders.

\section{SUBJECTS AND METHODS}

\section{Patients}

The five patients were evaluated by the Interdisciplinary Study Group of Disorders of Sex Development (GIEDDS) of the State University of Campinas, São Paulo. The protocol was approved by the local Ethics Committee (N. 434/06) and informed consent was obtained from the parents of the children included in the study.

\section{Laboratory assays}

LH, FSH, testosterone were measured by electrochemiluminescence (BM/Hitachi Elecsys 2010, Roche Diagnostics, Boehringer, Mannheim, Germany).

\section{Karyotype}

Chromosome analysis of peripheral blood lymphocytes was performed by G-banding at 500-600 bands resolution using standard procedures.

\section{Genomic DNA extraction, amplification and sequencing}

Genomic DNA from peripheral blood leukocytes was purified by Proteinase K digestion and phenol/chloroform extraction followed by ethanol precipitation using standard techniques (20). 
The 10 exons and the exon-intron junction regions of the WTI gene were PCR amplified from genomic DNA with primers described in Table 1 . Genomic sequence of the WTI gene was obtained in the published sequence ENSG00000184937 (www.ensembl.org).

The final volume of all reactions was $50 \mathrm{uL}$ and contained 10X Taq DNA polymerase buffer (Invitrogen, CA, USA), 1.0-1.5 mM MgCl2, $2 \mathrm{mM}$ of each dNTP, 20 pmol of each primer, 300-500 ng genomic DNA templates 2 units recombinant Taq DNA polymerase (Invitrogen), 5\% DMSO used only for exon 1. After a first denaturation step $\left(5 \mathrm{~min}, 94^{\circ} \mathrm{C}\right)$, the cycling profile was: $94^{\circ} \mathrm{C}, 1 \mathrm{~min} ; 53,5^{\circ} \mathrm{C}-63,5^{\circ} \mathrm{C}, 1 \mathrm{~min} ; 72^{\circ} \mathrm{C} 1-6$ min ( 30 cylcles), followed by $5 \mathrm{~min}$ at $72^{\circ} \mathrm{C}$ (final extension). The size of the PCR products was verified in $1 \%$ agarose gel electrophoresis stained with ethidium bromide. Before sequencing, purification of PCR products was performed using the Wizard ${ }^{\circledR}$ SV Gel and PCR clean-up system (Promega, Madison, WI, USA). Further direct sequencing using ABI PRISM Big Dye Terminator v3.1 Cycle Sequencing Kit (ABI PRISM/PE Biosystems, Foster City, CA, USA) was carried out in two separate reactions for each exon, except for exon 1 which required four reactions, using sense and antisense primers (Table 1). The sequences were obtained in an automatic sequencer ABI PRISM 3700 DNA Analyzer (ABI PRISM/PE Biosystems). Free softwares Chromas Lite and CLC Sequence Viewer v.5.0.1 were used to analyze and compare sequences with the published WTI sequence at Ensembl database.

\section{RESULTS}

\section{Case 1}

A 1-month-old child was referred to us due to sex ambiguity. He was born at term after an uneventful preg-

Table 1. Primers designed for WT1 coding sequence amplification.

\begin{tabular}{|c|c|c|c|c|c|}
\hline Primer & Direction & Sequences 5'-3' & $\mathrm{nt}^{2}$ & $\operatorname{Ta}\left({ }^{\circ} \mathrm{C}\right)^{3}$ & Size $(b p)^{4}$ \\
\hline \multirow[t]{2}{*}{ Exon 1} & Forward & TGAGTGAATGGAGCGGCCGAG & $512-532$ & 60.5 & 1049 \\
\hline & Reverse & TTGGGAAGCAGCTGGGTAAGAG & $1539-1560$ & & \\
\hline Intron $\left.1 \ln \right|^{1}$ & Forward & TTCATCAAACAGGAGCCGAG & $1211-1230$ & & \\
\hline Intorn $1 \operatorname{lnt}^{1}$ & Reverse & AAAGTGGACAGTGAAGGCGC & $1269-1288$ & & \\
\hline \multirow[t]{2}{*}{ Exon 2-3 } & Forward & CTGTCCCAAGGTCACATCCAG & $7324-7344$ & 57.5 & 1015 \\
\hline & Reverse & AAGTAGTAGAGTGGAGTCGAGGC & $8313-8338$ & & \\
\hline Intorn $2 \operatorname{lnt}^{1}$ & Reverse & ATTTGCTGTGGGTTAGGAATTC & $7710-7731$ & & \\
\hline Intron 2 Int $^{1}$ & Forward & GGCTAGCTTCTTGCATTCTG & $7921-7941$ & & \\
\hline \multirow[t]{2}{*}{ Exon 4-5 } & Forward & GATTTGCATATTCTGTCATTCTG & $18351-18373$ & 53.4 & 1406 \\
\hline & Reverse & ATGCTACCCTGATTACCCACG & 19737-19757 & & \\
\hline Intron $4 \operatorname{lnt}^{1}$ & Reverse & AAGCGTTCTAATGTCACAGAGAG & 18678-18700 & & \\
\hline Intron 4Int ${ }^{1}$ & Forward & GCACTCTTGATAGCTAGCTTGATG & 19475-19498 & & \\
\hline \multirow[t]{2}{*}{ Exon 6} & Forward & TGCATCTAAAGTGGCCCCATG & 35945-35965 & 57.5 & 375 \\
\hline & Reverse & AAAGGAGCCTGCAGTGAAGAAG & $36298-36319$ & & \\
\hline \multirow[t]{2}{*}{ Exon 7} & Forward & TGGGGATCTGGAGTGTGAATG & $39586-39606$ & 56.6 & 442 \\
\hline & Reverse & TCTTTACAACACCTGGATCAGACC & $40004-40027$ & & \\
\hline \multirow[t]{2}{*}{ Exon 8-9 } & Forward & TACCCTAACAAGCTCCAGCG & $43258-43277$ & 55,1 & 1037 \\
\hline & Reverse & TCTCTCAACTGAGTCTAAACCTTAG & $44271-44295$ & & \\
\hline Intorn $8 \ln ^{1}$ & Reverse & GAGAATCATGAAATCAACCCTAG & $43522-43544$ & & \\
\hline Intron $8 \operatorname{lnt}^{1}$ & Forward & TGAGGCAGATGCAGACATTG & $43949-43968$ & & \\
\hline \multirow[t]{2}{*}{ Exon 10} & Forward & CGGGCCTTGATAGTTGAACTTG & $46892-46913$ & 56.1 & 890 \\
\hline & Reverse & GITCTAAGAGCAGTGTGCCAG & $47759-47781$ & & \\
\hline
\end{tabular}

IInternal primers used only for sequencing; ${ }^{2}$ nucleotide position in the sequence ENSG00000184937; ${ }^{3}$ Anealing temperature used in PCR; ${ }^{4}$ size of amplified fragments. 
nancy with a birth weight of $3,655 \mathrm{~g}$ and length $50 \mathrm{~cm}$. $\mathrm{He}$ was the second child of unrelated parents and family history was unremarkable. He had a $2-\mathrm{cm}$ phallus with chordee, penoscrotal hypospadias, shawl scrotum, bilateral cryptorchidism, and there was no dysmorphic picture associated to sex ambiguity. Sonography revealed no mullerian derivatives while genitography showed a urogenital sinus.

His karyotype was $46, \mathrm{XY}$, and there were normal basal levels of $\mathrm{LH}(5.4 \mathrm{U} / \mathrm{L})$, FSH $(3.8 \mathrm{U} / \mathrm{L})$, free $(5.4 \mathrm{pg} / \mathrm{mL})$ and total $(157 \mathrm{ng} / \mathrm{dL})$ testosterone $(\mathrm{T})$. When the child was 6 months old, a hCG stimulation test was performed (three intramuscular injections of Chorionic Gonadotropin (Profasi ${ }^{\circledR}, 1,000$ IU, on successive days), and testosterone levels increased from 157 to $395 \mathrm{ng} / \mathrm{dL}$. He developed unilateral WT and chronic renal disease at 8 months, and died 2 months later as a result of septicemia.

An 1186G $>$ A heterozygous mutation was detected in exon 9 and confirmed the diagnosis of DDS; this case was first reported by Tagliarini and cols. (21).

\section{Case 2}

A 17.3-year-old girl was evaluated for primary amenorrhea and hypergonadotrophic hypogonadism. She was born at term after an uneventful pregnancy, with a birth weight of $3,560 \mathrm{~g}$ and length $46 \mathrm{~cm}$. She was the second child of unrelated parents, and family history was unremarkable. She was subject to renal transplantation at 11 years as a consequence of chronic renal disease; at the same age, bilateral inguinal hernia repair was performed.

She referred spontaneous pubertal onset. On physical examination, she had normal external genitalia and pubertal development was on Tanner stage B3P2.
There was no dysmorphic picture. Ultrasound revealed a $2.8 \mathrm{~cm}^{3}$ uterus, and gonads could not be found.

Her karyotype was $46, \mathrm{XY}$, and there were high levels of FSH $(188 \mathrm{U} / \mathrm{L})$ and $\mathrm{LH}(46 \mathrm{U} / \mathrm{L})$ and low estradiol $(1 \mathrm{lpg} / \mathrm{mL})$. Bilateral gonadectomy was performed, and histology revealed a right dysgenetic gonad with mesonephric remnants and a gonadoblastoma on the left. Female hormonal replacement therapy was initiated later on. Molecular analysis revealed an IVS9+4, C>T heterozygous mutation in intron 9 (Figure 1), thus confirming the diagnosis of Frasier syndrome.

\section{Case 3}

A 18-year-old girl was referred with a suspected diagnosis of FS to molecular analysis. She was the second child of unrelated parents, and family history was unremarkable. The girl had chronic renal disease treated with peritoneal dialysis, and primary amenorrhea was investigated when she was 15 years old - cytogenetic investigation revealed a 46,XY karyotype, bilateral gonadectomy was performed and histology revealed dysgenetic gonads. She has been on HRT since then.

On physical examination, she had no dysmorphic picture, external genitalia were normal, and breast development was incomplete.

Molecular analysis revealed the same mutation of case 2, thus confirming the diagnosis of FS.

\section{Case 4}

A 9-year-old boy presented with a history of sex ambiguity, aniridia, mental and motor retardation and dysmorphic features. He was born at term by cesarian section for breech presentation, after an uneventful pregnancy, with a birth weight of $2,550 \mathrm{~g}$. He was the

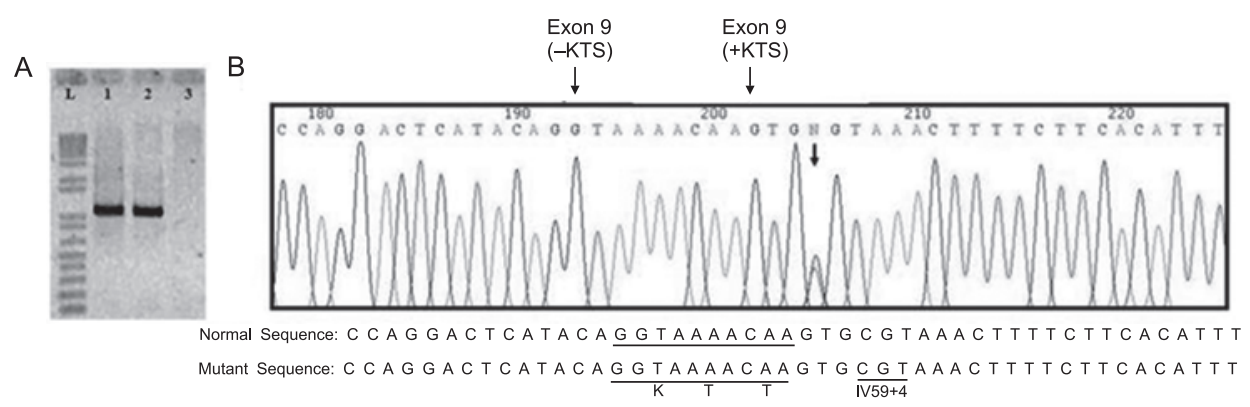

Figure 1. A) The 1037-bp exon 8-9 fragment was amplified by polymerase chain reaction (PCR). L- 1 kb-Plus Ladder (Invitrogen); patient (1), normal control (2), control without DNA (3); B) Eletropherogram of exon 9 sequence showing the C>T heterozygous mutation on WTI intron 9. The KTS motif and the positions of alternative splicings are denoted. 
first child in a sibship of three; his parents were not related, and family history was unremarkable.

Physical examination revealed flat occiput, small and dysmorphic ears, short upslanted palpebral fissures, aniridia, nystagmus, short nose with high nasal bridge, clinodactyly of the $\mathrm{V}$ fingers, bilateral single transverse palmar crease, predominance of arches on the fingertips, fusiform fingers, nail hypoplasia, increased intermamillary distance and diastasis recti. He had a $4.5 \mathrm{~cm}$-phallus, bifid scrotum, penoscrotal hypospadia and nonpalpable gonads.

Ophthalmologic evaluation revealed macular hypoplasia. The testes were not seen on pelvic ultrasound and genitography did not reveal a urogenital sinus.

He had prepubertal levels of $\mathrm{LH}(<0.2 \mathrm{U} / \mathrm{L}), \mathrm{FSH}$ $(0.4 \mathrm{U} / \mathrm{L})$, total $(<20 \mathrm{ng} / \mathrm{dL})$ and free $(1 \mathrm{pg} / \mathrm{mL})$ testosterone. An hCG stimulation test was performed, and testosterone levels increased from <20 to $396 \mathrm{ng} /$ $\mathrm{dL}$. Cytogenetic investigation revealed a de novo $46, \mathrm{XY}$, del( $1 \mathrm{lp}$ ) karyotype, thus leading to the diagnosis of WAGR syndrome.

\section{Case 5}

A 3-month-old boy was evaluated for aniridia and dysmorphic features. He was born in the $38^{\text {th }}$ week of gestation by cesarian section, and intrauterine growth retardation was noted at the $7^{\text {th }}$ month. Birth weight was $2,650 \mathrm{~g}$ and length $44 \mathrm{~cm}$. He was the only child of unrelated parents, and family history was unremarkable.

On physical examination, he presented high forehead, low anterior hairline, dysmorphic ears, anteverted nostrils, notched alae nasi, long and flat philtrum, thin upper lip, retrognathism, short neck, single transverse palmar crease and hypoplastic nails. He had a $3.5-\mathrm{cm}$ phallus, bilateral cryptorchidism and hypoplastic scrotum. Ophthalmologic evaluation revealed photophobia, nystagmus, remnants of pupillary membrane and peripheral iris and mottled retinal pigment epithelium.

He had normal levels of LH (9.5 U/L), FSH (8.8 $\mathrm{U} / \mathrm{L}$ ), and total testosterone ( $669 \mathrm{ng} / \mathrm{dL}$ ) for age. His karyotype was 46,XY, del (1lp) de novo (Figure 2), leading to the diagnosis of WAGR syndrome. When he was 8 months old, a unilateral Wilms tumour was detected by sonography. He was subject to nephrectomy, chemotherapy and radiotherapy. There was no tumor relapse until the age of 4 years, and renal function remained normal. Data on these five cases are summarized in Table 2.
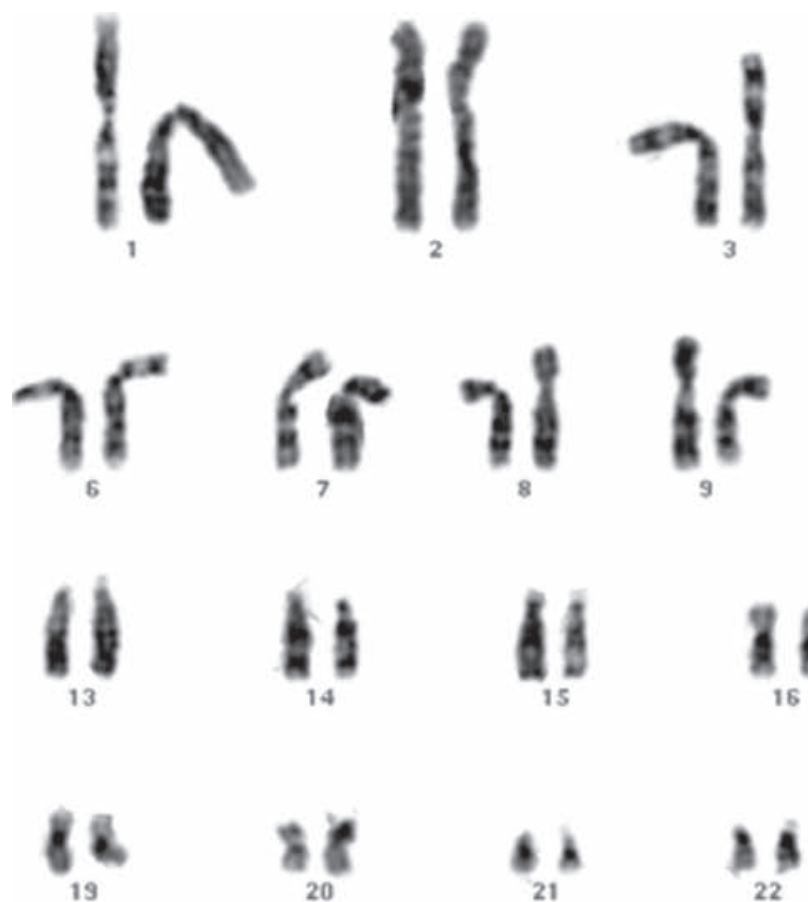

21
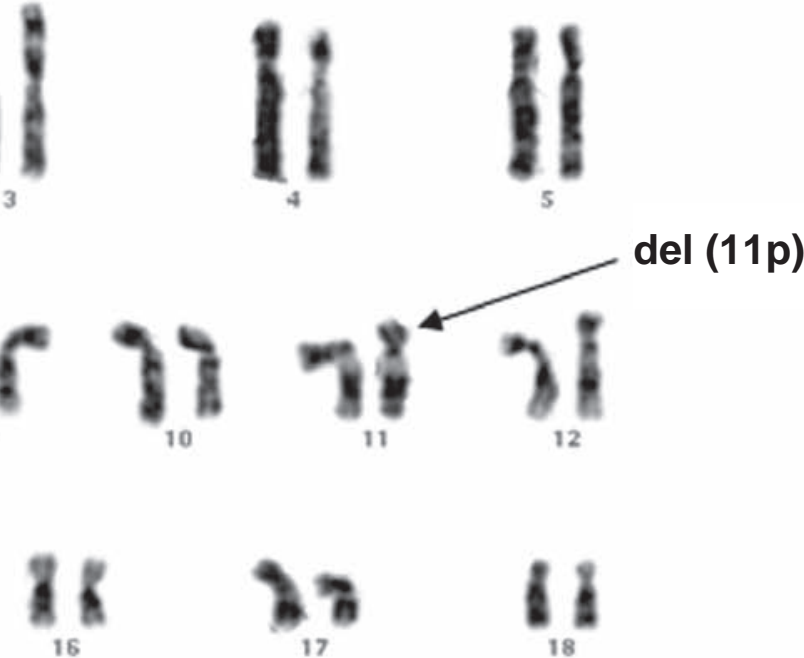

17
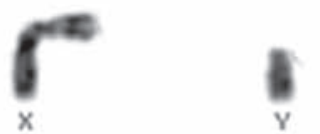

Figure 2. Karyotype of patient 5. 
Table 2. Description of five 46,XY patients with WT1-related disorders.

\begin{tabular}{|c|c|c|c|c|c|c|}
\hline $\mathbf{N}$ & $\begin{array}{l}\text { Age at } \\
\text { diagnosis }\end{array}$ & $\begin{array}{l}\text { Sex } \\
\text { assignment }\end{array}$ & Clinical picture & Neoplasia & $W T 1$ & Diagnosis \\
\hline 1 & $1 \mathrm{mo}$ & M & $\begin{array}{l}\text { penoscrotal hypospadias, } \\
\text { BL cryptorchidism, ESRD* }\end{array}$ & Wilms tumour & $1186 G>A$ & $\begin{array}{l}\text { Denys-Drash } \\
\text { syndrome }\end{array}$ \\
\hline 2 & $17 y$ & $\mathrm{~F}$ & $\begin{array}{l}\text { Primary amenorrhea, } \\
\text { hypergonadotrophic hypogonadism, ESRD }\end{array}$ & $\begin{array}{l}\text { L gonado- } \\
\text { blastoma }\end{array}$ & IVS9+4, C>T & $\begin{array}{l}\text { Frasier } \\
\text { syndrome }\end{array}$ \\
\hline 3 & $18 y$ & $\mathrm{~F}$ & $\begin{array}{c}\text { Primary amenorrhea, } \\
\text { hypergonadotrophic hypogonadism, ESRD }\end{array}$ & - & IVS9+4, C>T & $\begin{array}{l}\text { Frasier } \\
\text { syndrome }\end{array}$ \\
\hline 4 & $9 y$ & M & $\begin{array}{l}\text { Aniridia, perineal hypospadia, } \mathrm{BL} \\
\text { cryptorchidism, dysmorphic picture, motor } \\
\text { and speech delay, mental deficiency }\end{array}$ & - & 11 p13 deletion & WAGR \\
\hline 5 & $2 \mathrm{mo}$ & M & $\begin{array}{l}\text { Aniridia, BL cryptorchidism, dysmorphic } \\
\text { picture, motor and speech delay }\end{array}$ & Wilms tumour & 11 p13 deletion & WAGR \\
\hline
\end{tabular}

$\mathrm{BL}=$ bilateral; $\mathrm{ESRD}=$ end stage renal disease; $\mathrm{F}=$ female; $\mathrm{L}=$ left; $\mathrm{M}=$ male; $\mathrm{NB}=$ newborn; *deceased (10 months)

\section{DISCUSSION}

Disorders of gonadal development (DGD) are a highly heterogeneous group of disorders of sex development (DSD) and include individuals with dysgenetic gonads (streaks), dysgenetic or rudimentary testes and true hermaphroditism or ovotesticular DSD. Some 46,XY individuals with DGD are born with sex ambiguity, and thus may be evaluated in infancy. However, those with female internal and external genitalia (male-to-female sex reversal) may be diagnosed only in adolescence because of pubertal delay. The latter are of great concern because of the risk of neoplastic transformation of dysgenetic gonads, which is significantly elevated after adolescence (22). Hormonal activity of gonadoblastoma may be found in some patients (23); in case 2, for instance, there was spontaneous breast development which may be due to an estrogen-producing gonadoblastoma.

Among DGD, WTl-related disorders are characterized by the association of gonadal and renal anomalies. As a consequence, screening for mutations in WTI should be considered in 46,XY patients with ambiguous genitalia associated with chronic renal disease and (or) WT and in 46,XY females with hypergonadotrophic hypogonadism and history of chronic renal disease, thus allowing the diagnosis of DDS and FS.

In addition, all newborns with aniridia who do not have a family history of this ocular anomaly must be subject to high-resolution cytogenetic testing, which detects deletions involving $1 \mathrm{lpl} 3$ in up to $20 \%$ of indi- viduals (24). FISH testing with probes spanning $P A X 6$, $W T 1$, the regions flanking $P A X 6$, and the intervening sequence between PAX6 and WTI can also be used to detect cryptic deletions in individuals with other clinical features of WAGR and normal cytogenetic studies (24).

Genotype-phenotype correlations in WTl-related disorders are well established. Mutations in DDS patients inactivate DNA binding by the zinc fingers, leading to early and severe impairment of renal function, dysgenetic testes and high incidence of WT, while in FS mutations in the donor splice site of intron 9 of the WTI gene lead typically to dysgenetic gonads, end-stage renal failure in the second decade and gonadoblastoma. In turn, the reduced haploinsufficiency of WTI in 11 pl 3 deletion has a less pronounced effect on development, especially on that of the renal system.

However, there are some reports of atypical presentations, including a 46,XY child with sex ambiguity, nephrotic syndrome, gonadal tumour and normal testosterone production despite high levels of gonadotropins, who had a mutation associated with FS (25), In another study, a 46,XY child with sex ambiguity, normal testosterone production, aortic coarctation and no renal disease was found to have a P181S mutation in WTI inherited from the mother (26).

Diagnosis of WTl-related disorders is more difficult in 46,XX subjects, who lack features of sex ambiguity and sex reversal. However, clinicians must have in mind that WTl mutations may be found in up to $5 \%$ of 
cases of steroid-resistant nephrotic syndrome (SRNS) (27-28). Routine evaluation of patients with this syndrome would allow early diagnosis of both DDS and FS in both sexes.

The heterozygous $1186 \mathrm{G}>\mathrm{A}(\mathrm{D} 396 \mathrm{~N})$ mutation in exon 9 of patient 1 leads to an aspartic acid-asparagine substitution changing the structural organization of the third zinc finger of the WTl protein. It was described in 1991 (13) and is a frequent finding in DDS; the most frequent mutation is $1180 \mathrm{C}>\mathrm{T}$ (R394W) (39.6\%) (29). The apparent dominant-negative nature of DDS mutations results from the action of altered WTl in blocking the normal activity of the wildtype protein (12).

The heterozygous mutation in intron 9 found in both patients with FS (IVS9+4, C>T) is the most frequent mutation identified in these patients $(52 \%)$ $(15,25)$. This and the other four different mutations described in intron 9 of $W T l$ in patients with FS lead to reversal of the $(+\mathrm{KTS}) /(-\mathrm{KTS})$ ratio from 2:1 to $1: 2$ (15-16). Most of the patients with FS show the $+4 \mathrm{C}>\mathrm{T}$ and $+5 \mathrm{G}>\mathrm{A}$ mutations; this hotspot is probably a consequence of the potential to deaminate 5 -methylcytosine at the $+4 /+5 \mathrm{CpG}$ dinucleotide (16).

Recurrence risk of WTl-related disorders varies according to each specific situation. DDS and FS usually arise as a consequence of de novo mutations, while $1 \mathrm{lp}$ deletion in WAGR syndrome may be de novo or may result from transmission by a parent with a balanced chromosome rearrangement (24).

In conclusion, constitutional abnormalities of WT1 should be considered in patients with ambiguous genitalia and renal disease (chronic renal disease or Wilms tumors), primary amenorrhea with chronic renal disease, and those with aniridia, genital ambiguity and dysmorphic picture with or without WT.

Acknowledments: We are grateful to the Main Clinical Laboratory of the University Hospital and to the Cytogenetics Laboratory of the Department of Medical Genetics of State University of Campinas (Unicamp). No potencial conflict of interest relevant to this article was reported.

\section{REFERENCES}

1. Luo $\mathrm{X}$, Ikeda, Y, Parker, KL. A cell-specific nuclear receptor is essential for adrenal and gonadal development and sexual differentiation. Cell. 1994;77:481-90.
2. Swain A, Zanaria E, Hacker A, Lovell-Badge R, Camerino G. Mouse Dax1 expression is consistent with a role in sex determination as well as in adrenal and hypothalamus function. Nature Genet. 1996;12:404-9.

3. Pritchard-Jones K, Fleming S, Davidson D, Bickmore W, Porteous D, Gosden C, et al. The candidate Wilms' tumour gene is involved in genitourinary development. Nature. 1990;346: 194-7.

4. Rose EA. Glaser T, Jones C, Smith CL, Lewis WH, Call, KM, et al. Complete physical map of the WAGR region of $11 \mathrm{p} 13$ localizes a candidate Wilms' tumour gene. Cell. 1990;60:405-508.

5. Call KM, Glaser T, Ito CY, Buckler AJ, Pelletier J, Haber DA, et al. Isolation and characterization of a zinc finger polypeptide gene at the human chromosome 11 Wilms' tumour locus. Cell. 1990;60:509-20.

6. Gessler M, Konig A, Bruns GAP. Homozygous deletion in Wilms tumours of a zinc-finger gene identified by chromosome jumping. Nature. 1990;343:774-8.

7. Pritchard-Jones K, Fleming S, Davidson D, Bickmore W, Porteous D, Gosden C, et al. The candidate Wilms' tumour gene is involved in genitourinary development. Nature. 1990;346: 194-7.

8. Haber DA, Sohn RL, Buckler AJ, Pelletier J, Call KM, Housman $\mathrm{DE}$. Alternative splicing and genomic structure of the Wilms tumour gene WT1. Proc Nat Acad Sci. 1991;88:9618-22.

9. Laity $\mathrm{JH}$, Chung J, Dyson $\mathrm{HJ}$, Wright PE. Alternative splicing of Wilms' tumour suppressor protein modulates DNA binding activity through isoform-specific DNA-induced conformational changes. Biochemistry. 2000;39:5341-8.

10. Hossain A, Saunders GF. The human sex-determining gene SRY is a direct target of WT1. J Biol Chem. 2001;276:16817-23.

11. Nachtigal MW, Hirokawa $Y$, Enyeart-VanHouten DL, Flanagan JN, Hammer GD, Ingraham HA. Wilms' tumour 1 and Dax-1 modulate the orphan nuclear receptor SF-1 in sex-specific gene expression. Cell. 1998;93:445-54.

12. Moffett $P$, Bruening $W$, Nakagama $H$, Bardeesy $N$, Housman $D$, Housman DE, Pelletier J. Antagonism of WT1 activity by protein self-association. Proc Natl Acad Sci USA. 1995;92:11105-9.

13. Pelletier J, Bruening W, Kashtan CE, Mauer SM, Manivel JC, Striegel JE, et al. Germline mutations in the Wilms' tumor suppressor gene are associated with abnormal urogenital development in Denys-Drash syndrome. Cell. 1991;67(2):437-47.

14. Patek CE, Little MH, Fleming S, Miles C, Charlieu JP, Clarke AR, et al. A zinc finger truncation of murine WT1 results in the characteristic urogenital abnormalities of Denys-Drash syndrome. Proc Natl Acad Sci USA. 1999;96(6):2931-6.

15. Barbaux S, Niaudet $P$, Gubler M-C, Grunfeld J-P, Jaubert F, Kuttenn $\mathrm{F}$, et al. Donor splice-site mutations in WT1 are responsible for Frasier syndrome. Nature Genet. 1997;17:467-70.

16. Klamt B, Koziell A, Poulat F, Wieacker P, Scambler P, Berta P, Gessler M. Frasier syndrome is caused by defective alternative splicing of WT1 leading to an altered ratio of WT1 +/-KTS splice isoforms. Hum Mol Genet. 1998;7(4):709-14.

17. Miller RW, Fraumeni Jr. JF, Manning MD. Association of Wil$\mathrm{ms}^{\prime}$ tumour with aniridia, hemihypertrophy and other congenital malformations. New Eng J Med. 1964;270:922-7.

18. Schmickel RD. Chromosomal deletions and enzyme deficiencies. J Pediat. 1986;108:244-6.

19. Gessler M, Poustka A, Cavenee W, Neve RL, Orkin SH, Bruns GAP. Homozygous deletion in Wilms tumours of a zinc-finger gene identified by chromosome jumping. Nature. 1990;343: 774-8. 
20. Sambrook J, Fritsch EF, Maniatis TE. Molecular cloning, a laboratory manual. Cold Spring Harbor, New York. 1989.

21. Tagliarini EB, Assumpção JG, Scolfaro MR, Mello MP, MacielGuerra AT, Guerra Júnior G, et al. Mutations in SRY and WT1 genes required for gonadal development are not responsible for $\mathrm{XY}$ partial gonadal dysgenesis. Braz J Med Biol Res. 2005;38(1):17-25.

22. Verp MS, Simpson JL. Abnormal sexual differentiation and neoplasia. Cancer Genet Cytogenet. 1987;25:191-218.

23. Hoepffner W, Horn LC, Simon E, Sauerbrei G, Schröder H, Thamm-Mücke B, et al. Gonadoblastoma in 5 patients with 46,XY gonadal dysgenesis. Exp Clin Endocrinol Diabetes. 2005;113(4):231-5.

24. Hingorani M, Moore A. Aniridia. In: GeneReviews at GeneTests: Medical Genetics Information Resource (database on the internet). Seattle: University of Washington, 2002 [Updated 2008 July 12; cited 2008 August 19]. Available from: http:// www.genetests.org.

25. Melo KF, Martin RM, Costa EM, Carvalho FM, Jorge AA, Arnhold IJ, et al. An unusual phenotype of Frasier syndrome due to IVS9 +4C>T mutation in the WT1 gene: predominantly male ambiguous genitalia and absence of gonadal dysgenesis. $\mathrm{J}$ Clin Endocrinol Metab. 2002;87(6):2500-5.
26. Köhler B, Pienkowski C, Audran F, Delsol M, Tauber M, Paris F, et al. An N-terminal WT1 mutation (P181S) in an XY patient with ambiguous genitalia, normal testosterone production, absence of kidney disease and associated heart defect: enlarging the phenotypic spectrum of WT1 defects. Eur J Endocrinol. 2004; 150(6):825-30.

27. Cho HY, Lee JH, Choi HJ, Lee BH, Ha IS, Choir Y, et al. WT1 and NPHS2 mutations in Korean children with steroid-resistant nephrotic syndrome. Pediatr Nephrol. 2008;23(1):63-70.

28. Gbadegesin R, Hinkes B, Vlangos C, Mucha B, Liu J, Hopcian $\mathrm{J}$, et al. Mutational analysis of NPHS2 and WT1 in frequently relapsing and steroid-dependent nephrotic syndrome. Pediatr Nephrol. 2007;22(4):509-13.

29. Little M, Wells C. A clinical overview of WT1 gene mutations. Hum Mutat. 1997;9(3):209-25.

\section{Correspondence to:}

Andréa Trevas Maciel Guerra

Department of Medical Genetics, Faculty of Medical Sciences, PO Box 6111 , Unicamp

13083-970, Campinas, SP, Brazil

E-mail: atmg@fcm.unicamp.br 